\title{
Management Strategies to Improve Reproductive Performance of Brahman Cross Cattle (Bos indicus) in East Java, Indonesia
}

\author{
Ratnawati $\mathrm{D}^{1}$, Indrakusuma $\mathrm{DA}^{1}$, Affandhy $\mathrm{L}^{1}$, Cowley $\mathrm{F}^{3}$, Mayberry $\mathrm{D}^{4}$, Poppi $\mathrm{D}^{2}$ \\ ${ }^{1}$ Beef Cattle Research Station, Grati-Pasuruan, East Java, Indonesia \\ ${ }^{2}$ School of Agriculture and Food Sciences, The University of Queensland, Gatton, Queensland, Australia \\ ${ }^{3}$ School of Environmental and Rural Science, University of New England, Armidale New South Wales, Australia \\ ${ }^{4}$ CSIRO Agriculture, St Lucia, Queensland, Australia \\ E-mail: dian_sapo@yahoo.co.id
}

(received 12-08-2016; revised 15-11-2016; accepted 23-11-2016)

\begin{abstract}
ABSTRAK
Ratnawati D, Indrakusuma DA, Affandhy L, Cowley F, Mayberry D, Poppi D. 2017. Strategi manajemen untuk meningkatkan perfomans produksi reproduksi sapi Brahman Cross (Bos indicus) di Jawa Timur, Indonesia. JITV 21(4): 231-237. DOI: http://dx.doi.org/10.14334/jitv.v21i4.1512

Produksi ternak nasional belum dapat mencukupi kebutuhan dalam negeri sehingga pemerintah melakukan importasi sapi Brahman ke Indonesia. Banyak issue menyatakan bahwa sapi Brahman mempunyai banyak permasalahan reproduksi. Tujuan penelitian ini adalah mengetahui tampilan reproduksi sapi Brahman cross melalui perbaikan manajemen pemeliharaan, diantaranya: mempertahankan skor kondisi tubuh induk $>3$, deteksi birahi dan perkawinan yang tepat serta penyapihan pada umur 5-6 bulan. Penelitian dilakukan pada oktober 2011 - desember 2013 dengan menggunakan materi awal ternak berjumlah 189 ekor dengan total peternak yang terlibat 151 orang. Lokasi penelitian adalah 2 kecamatan di kabupaten Lamongan (Jawa Timur), yaitu: modo dan sambeng. Pakan yang diberikan adalah hasil samping pertanian (potensi lokal) dan suplementasi induk menggunakan pakan hijauan, dedak padi dan konsentrat (2 bulan akhir kebuntingan dan awal laktasi). Terdapat peningkatan tampilan reproduksi sapi brahman pada akhir tahun penelitian. Durasi estrus setelah beranak, siklus sampai perkawinan dan masa kosong lebih pendek pada akhir penelitian daripada kondisi sebelumnya, yaitu: 98 hari, 64 hari dan 118 hari. Kondisi ini berhubungan dengan kondisi induk yang baik saat melahirkan (dari 3,0 menjadi 3,3) dan didukung oleh masa laktasi yang lebih pendek (153 hari). Tampilan produksi pedet menunjukkan rataan bobot lahir 31-32 kg. Penyapihan dini dilakukan pada umur 153 hari dengan rataan bobot sapih 139,6 kg dan pertambahan bobot badan harian (PBBH) $0,7 \mathrm{~kg} / \mathrm{hari}$. Tingkat kematian pedet semakin menurun sepanjang tahun (6\%). Dapat disimpulkan bahwa teknologi perbaikan manajemen, diantaranya: mempertahankan skor kondisi tubuh induk $>3$, deteksi birahi dan perkawinan yang tepat serta penyapihan pada umur 5-6 bulan dapat memperbaiki tampilan reproduksi sapi Brahman cross.
\end{abstract}

Kata Kunci: Reproduksi, Sapi, Brahman Cross

\section{ABSTRACT}

Ratnawati D, Indrakusuma DA, Affandhy L, Cowley F, Mayberry D, Poppi D. 2017. Management strategies to improve reproductive performance of Brahman cross cattle (Bos indicus) in East Java, Indonesia. JITV 21(4): 231-237. DOI: http://dx.doi.org/10.14334/jitv.v21i4.1512

The demand for meat in Indonesia cannot be supplied by domestic cattle production, and so government imported breeding stock from abroad to increase domestic production. A commonly imported breed is Brahman cross bred (Bx). Smallholder farmers have reported a wide range of problems associated with reproductive performance of $\mathrm{Bx}$. The purpose of this study was to identify changes in the reproductive performance of $\mathrm{Bx}$ cows by providing advice to farmers on improved management strategies, such as: maintaining body condition score (BCS) of cow>3, appropriate estrous detection and weaning at 5- 6 months. This study was conducted from October 2011 - December 2013 by using 189 Bx cows and 151 farmers. The research was conducted in two sub districts of Lamongan district (East Java), Modo and Sambeng. Cattle were fed diets based on crop residues and were supplemented with green feeds, by-products (rice bran) and concentrate during the last 2 months of pregnancy and early lactation. The reproductive performance of cows improved during the study, there were a shorter lactation length/earliery weaning (reduced from 188 days to 153 days) and improved BCS (from 3.0 to 3.3). The length of postpartum anestrous interval (PPAI) decreased from 198 days to 98 days. Cycling to conception decreased from 75 days to 64 days and days open decreased from 217 days to 118 days over the length of the study. This was associated with improvement in BCS of cows at calving (from 3.0 to 3.3) and a shorter lactation length (reduced from 188 days to 153 days). There was no change in the average birth weight of calves $(31.8 \mathrm{~kg})$. There was no change in average weaning weight of calves over the year and average daily gain of calves while suckling $0.7 \mathrm{~kg} /$ day. The pre weaning calf mortality rate was decreased during this study (from $13 \%$ to $6 \%$ ). This project demonstrated that Brahman cross cows can successfully be kept by smallholder farmers in Indonesia if appropiate management is applied. It is concluded that improving management, such as maintaining body condition score of cow $>3$, estrous detection, appropiate mating and weaning at 5-6 months can improve reproduction performance of Brahman cross.

Key Words: Reproduction, Cattle, Brahman Cross 


\section{INTRODUCTION}

The total beef cattle population in Indonesia has decreased in recent years from 12,686 million (2013) to 16,004 million heads (2016) (DGLAH 2017). High demand for beef, which is not balanced with supply of domestic cattle exacerbates this condition. Beef consumption was $6.413 \mathrm{~kg}$ in 2015 and increased by $5.69 \%$ in $2016(6.778 \mathrm{~kg})$. The government of Indonesia has implemented several policies, with the aim of helping Indonesia to become self-sufficient in beef production. Strategies developed to increase beef production include importing Brahman (Bos indicus) cattle from Australia, national breeding policy (refining local cattle, developing a commercial production of local cattle), strengthening national food security (availability of food and feed), increasing local cattle population, substitution of beef with poultry, fishery, and sheep products and specific institutional policy (improvement of coordination between institution, optimizing organization for rescue productive cows and proven breed) (Rusono 2011).

Brahman cattle have a large mature size and a faster growth rate (Tatman et al. 2004) than local Indonesian cattle (e. g. Bali (Bos javanicus) and Ongole (Bos indicus) breeds), when they are managed well and kept in good condition. However, Brahman cows also have higher maintenance energy requirements compared to local cattle (Antari et al. 2014a; Antari et al. 2014b), and many smallholder farmers have reported problems with low growth rates and long inter-calving intervals (Ciccioli et al. 2003). This means that farmers invest considerable amounts of time, labor and money before they have a calf ready for sale. Long calving intervals are driven by long post-partum anestrus interval (PPAI) and repeated, unsuccessful mating (Ciccioli et al. 2003). These problems may be caused by inadequate nutrition, lack of weaning management, poor estrous detection and poor mating management (Syarifuddin \& Wahdi 2008).

Nutrition has a big influence on the reproductive performance of cows. The most critical time in the cow's reproduction cycle is during late pregnancy and early lactation when the foetus and calf place large energy demands on the cow. Body Condition Score (BCS) can be used as an indication of nutritional status. Body condition scre (BCS) $\geq 3$ (1-5 scale) at time of calving increases the likelihood of the cow returning to oestrus. Ratnawati et al. (2014) reported that Brahmancross cows in East java villages with BCS 3.1-3.3 have a PPAI of 110-135 days. PPAI is defined as the interval from calving to first oestrus after calving. A PPAI length of 110-135 days will allows cow to produce a calf every year. A longer PPAI reduces reproductive efficiency by delaying new calves and reducing the number of calves during her lifetime. Poor nutrition affects PPAI by suppressing hypothalamic secretion of GnRH (gonadothrophin releasing hormone) which stimulates the adenohypofise (anterior pituitary) to secrete LH (Luteinizing Hormone). Low secretion of LH, causes delayed ovulation (Nogueira 2004), extends the time to return to estrous after calving (Boland \& Lonergan 2003) and extends calving interval.

Lactation is another cause of extended PPAI, especially in Bos indicus cattle breeds such as Brahmans. Suckling stimulates the pituitary gland to release prolactin, which inhibits the production of hormones necessary for ovulation (Goff 2015). Weaning calves earlier will therefore support the cow to start cycling by removing the suckling stimulus and reducing energy demands for lactation.

Poor estrous detection may also be affecting successful reproduction in Brahman cows in Indonesia (Tambunan et al. 2013). Most cows in East Java are mated using artificial insemination (AI). Accurate detection of estrous by the farmer and timely insemination are therefore crucial to improving the likelihood of successful mating. Inaccurate oestrous detection is caused by many factors, including: silent heat, insufficient time devoted by farmers to checking for sign of oestrus, or farmers observe inappropiate signs of oestrus. Ratnawati et al. (2014) reported that Brahman-cross bull in Lamongan district of East Java were given free access for oestrous detection and natural mating, was able to reduce the time from calving to conception from an average of 196 to 123 days .

An integrated village management system (IVMS) of nutritional, reproductive and health components was able to improve reproductive efficiency in Bali cows in Eastern Indonesia (Poppi et al. 2011). This system uses improved management strategies such as strategic supplementation of cows to maintain a $\mathrm{BCS} \geq 3 / 5$, timely detection of oestrous, properly mating management and weaning of calves at or before 6 months of age.

It was hypothesised that adapting the strategies of the IVMS to Brahman-cross cows in East Java will also improve their reproductive performance.

\section{MATERIALS AND METHODS}

Brahman-cross cows kept by smallholders in Sambeng and Modo sub-districts of Lamongan district (East Java), were monitored for their reproductive performance and management. The study was conducted between October 2011 and December 2013. The total number of farmer and cattle involved in this study is shown in Table 1. Different numbers of farmers and cattle were involved in the study each year because some farmers sold their cows for any reason. 
Table 1. Number of farmer and cattle involved in this study from 2011-2013

\begin{tabular}{lccc}
\hline \hline & \multicolumn{3}{c}{ Year of study } \\
\cline { 2 - 4 } & 2011 & 2012 & 2013 \\
\hline Number of farmers & 151 & 148 & 105 \\
Number of cow & 189 & 183 & 126 \\
\hline
\end{tabular}

Farmers received regular individual visits from project staff throughout the project. Project staff collected data on animal performance and provided advice on implementing the management strategies of the IVMS described above (weaning of calves, maintaining good BCS, oestrous detection and appropriate feeding). Interaction with project farmers included both formal farmer group meetings and farmer visit) and informally (regular visit at list once a month).

\section{Feeding management}

Cattle were fed diets based on crop residues (rice straw and corn stover), and were supplemented with green roughages (mostly grasses, but also tree legumes), by-products (rice bran) and a commercial concentrate (yellow feed SPT-01). The composition of the yellow feed SPT-01 concentrate (at the packet) were; water (max $12 \%)$, crude protein ( $\min 16 \%)$, crude fat $(\min 4 \%)$, crude fiber $(\max 11 \%)$, ash $(\max 10 \%)$, TDN (min 67\%), Ca (0.9-1.2\%) and P (0.6-0.8\%). Tree legumes (Gliricidia sepium, Sesbania grandiflora and Leucaena leucocephela) were planted by farmers and project staff around the village sites, and farmers were encouraged to cut and feed these forages to cows. The yellow feed SPT-01 concentrate was provided by the project for cows in the last two months of pregnancy and in early lactation (approximately $2 \mathrm{~kg}$ $\mathrm{DM} /$ head/day) in addition to their normal daily ration. Feed offered by the farmer was monitored and recorded (sub-sample 38 farmers/ month).

\section{Mating management}

Most cows were kept tethered in individual pens and mated using AI. Farmers monitored signs of estrous, and AI was conducted by the local inseminator. Timing of AI depended on availability of inseminator, but generally, if the farmer reported in the morning, AI would be done on the same day. However, if farmers noticed signs of estrous and reported in the afternoon, AI was conducted on the following morning.

One farmer kept their cattle untethered in communal pen with a bull, and it was assumed that cows were mated whenever the bull detected cow oestrus.

\section{Weaning of calves}

Farmers were encouraged to wean calves at 5-6 months of age. Calves were physically separated from the cows at weaning so they were not able to suckle. Many farmers chose to sell calves at weaning.

\section{Measurements and data analyses}

Cows and calves and BCS (visual assessment, 1-5 scale) were measured monthly during the first year of the project and every two months thereafter. Dates of oestrous detection, mating, calving and weaning were also recorded. Oestrous was detected by visual observation of restlessness, presence of clear mucus, standing to be mounted, swelling and reddening of vulva. This information was used to calculate average daily live weight gain (ADG) of calves, PPAI (days from calving to first observed oestrus), time from cycling to conception (days from first observed oestrus to conception), days open (days from calving to conception), length of lactation and incidence of lactation anoestrous (failure to show signs of oestrous while lactating). Average cow weight was corrected for pregnancy using the method of Silvey \& Haydock (1978), which adjusts weight based on day of gestation and birthweight of calf. Daily climate data (temperature, rainfall) was collected from Lamongan district government weather station.

Data was analyzed using Microsoft excel and SPSS (one way anova). All procedures were reviewed and approved by the University of Queensland Animal Ethics Committee in accordance with the Australian Code of Practice for the Care and Use of Animals for Scientific Purposes.

\section{RESULTS AND DISCUSSION}

\section{Feeding management}

The feeding system of Brahman cows in Lamongan depended on the availability of local feed sources. There were many kinds of local feed resourses used, which was categorized into three categories, there were: basal diet, medium quality greenfeed and high quality feed. On the average, cows in this study were offered $12.7 \mathrm{~kg}$ of basal diet; $25.1 \mathrm{~kg}$ of medium greenfeed and $3.1 \mathrm{~kg}$ of high quality of feed each day. The basal diet consisted of low quality feeds, mainly rice straw and corn stover. Medium quality greenfeed included native grasses elephant grass, tree legumes, and sugarcane tops. A small number of farmers fed, 
Table 2. Availability of feeds during the study

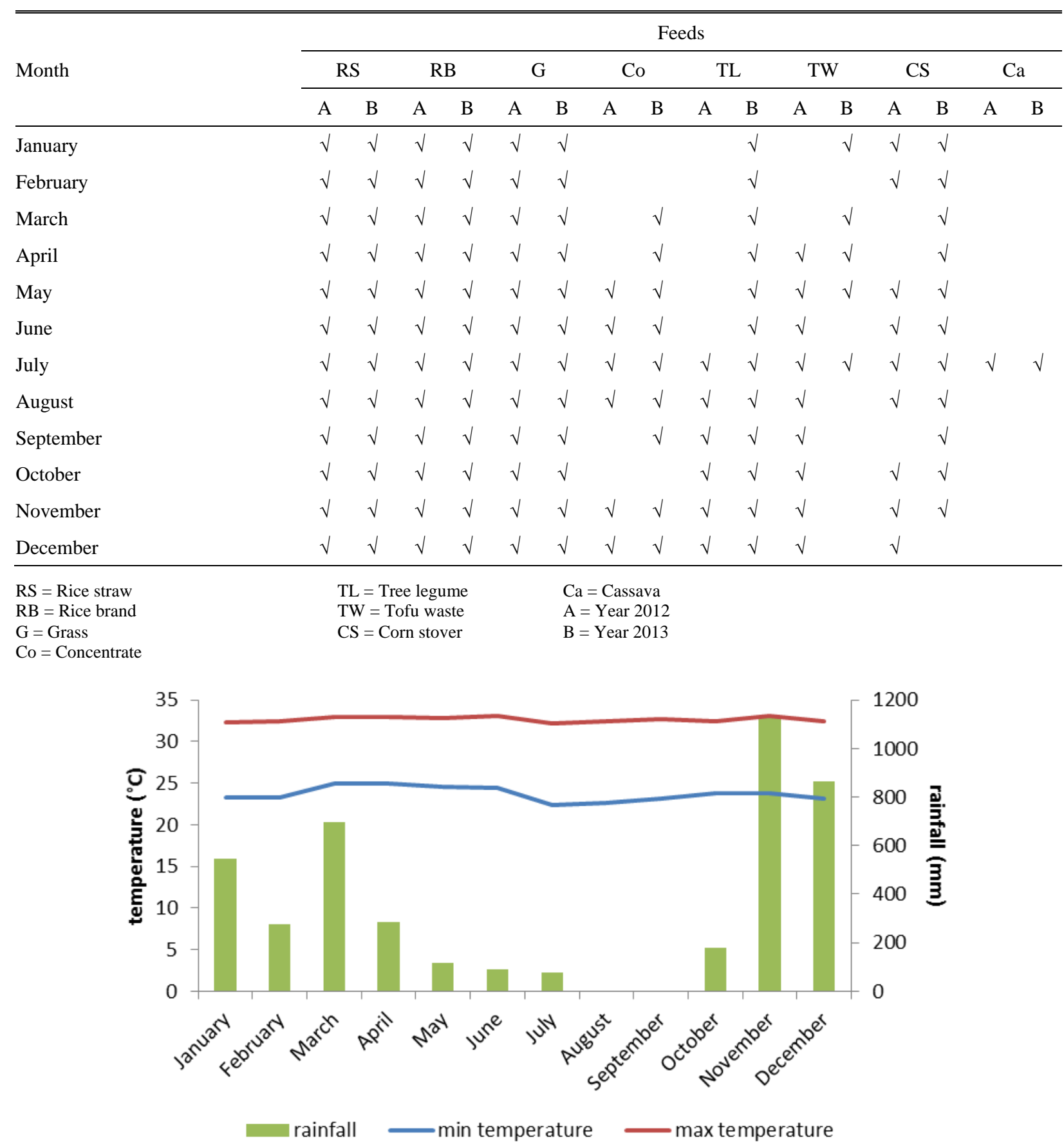

Figure 1. Average minimum and maximum temperature and rainfall in Lamongan district during the study (2011-2013).

their cattle high quality feeds such as chopped cassava, The availability of feed during the study shown in Table cassava peel, onggok (cassava by-product), tofu waste and grain concentrates (rice brand, yellow feed, concentrate etc).We recorded types and amount of feed given by 10-20 farmers to the cattle in every subdistrict. 2.

Farmer gave feeds to the cattle as a mixture of many feeds. In the wet season (November to March, Figure 1 ), the availability and digestibility of green feed is higher than in the dry season (April to October). 
Table 2. Reproductive performance of Brahman cows in Lamongan, East Java (mean \pm SD)

\begin{tabular}{lccc}
\hline \hline & \multicolumn{3}{c}{ Year of study } \\
\cline { 2 - 4 } & 2011 & 2012 & 2013 \\
\hline Average post-partum anestrous interval (days) & $198^{\mathrm{a}} \pm 31$ & $143^{\mathrm{b}} \pm 9$ & $98^{\mathrm{c}} \pm 6$ \\
Average time from cycling to conception (days) & - & $75 \pm 17$ & $64 \pm 12$ \\
Average days open (days) & - & $217 \pm 13$ & $118 \pm 7$ \\
Average lactation length (days) & $188^{\mathrm{a}} \pm 7$ & $169^{\mathrm{b}} \pm 15$ & 88 \\
Cows pregnant $1^{\text {st }}$ mating (\%) & 6 & 42 & 92 \\
Cows mated with AI (\%) & 86 & 86 & 33 \\
Cows pregnant within 100 days of calving (\%) & - & 13 & 3 \\
Cows with lactation anestrous (\%) & 50 & 39 & $3.3 \pm 0.1$ \\
BCS of cows at calving (1-5 scale) & $3 \pm 0.1$ & $3.3 \pm 0.1$ & 10 \\
Cows in BCS $<3$ at calving (\%) & 17 & 22 & 390 \\
Average cow weight corrected for pregnancy (kg) & - & 363 & 3 \\
\hline
\end{tabular}

a,b,c Different letters within rows indicate significant differences at $\mathrm{P}<0.05$

Table 3. Brahman calf production (mean $\pm \mathrm{SE}$ )

\begin{tabular}{lccc}
\hline \hline & \multicolumn{3}{c}{ Year of Study } \\
\cline { 2 - 4 } & 2011 & 2012 & 2013 \\
\hline Number calves born (\%) & 8 & 65 & 66 \\
Average birth weight (kg) & $31 \pm 2$ & $31 \pm 0$ & $32 \pm 0$ \\
Average weaning weight (kg) & $164 \pm 13$ & $139 \pm 4$ & $140 \pm 5$ \\
Average age at weaning (days) & $188^{\mathrm{a}} \pm 15$ & $169^{\mathrm{a}} \pm 3$ & $153^{\mathrm{b}} \pm 3$ \\
ADG while suckling (kg/day) & $0.7 \pm 0.1$ & $0.7 \pm 0$ & $0.7 \pm 0$ \\
Mortality rate (\%) & 13 & 5 & 6 \\
\hline
\end{tabular}

${ }^{\mathrm{a}, \mathrm{b}}$ Different letters within rows indicate significant differences at $\mathrm{P}<0.05$

During the dry season, additional supplementation from concentrates or by-products was necessary to maintain cow BCS. Planting tree legumes can increase the availability of green feeds during the dry season, when grasses reach maturity and growth slows (Shelton 2004). Farmers could also manage cattle so that periods of high energy requirements (e. g. late pregnancy and early lactation) coincide with the middle of the wet season when higher quality feed is available.

Adequate feed quantity and quality around the time of parturition is necessary to maintain BCS and support the reproductive performance of the cow. Body condition score has a significant impact to ovarían cyclicity and pregnancy rate of beef cows. Improved $\mathrm{BCS}$ and nutrition may also have improved corpus luteum viability and embryo survival. For smallholders, high quality green feeds (such as gliricidia, sesbania, leucaena) are a good source of protein (Antari et al. 2014a) and highly digestible energy to increase reproduction performance.

\section{Reproductive performance of cows}

Improvement in reproductive performance of cows was recorded during the periode of this study (Table 2). There was an increased percentage of pregnancy at first mating and decreased percentage of cows with lactation anoestrus between 2011 and 2013. The PPAI was shorter in 2013 than that in 2011 and 2012, and the percentage of pregnancy within 100 days of calving increased from 13 to $33 \%$. The PPAI decreased by 100 days between 2011 and 2013. This shorter time from calving to first oestrous may be related to improvement in BCS of cows at calving (Ciccioli et al. 2003; Meikle et al. 2004). Although there was not a significant increase in the average BCS of cows at calving during 
the study, there was decrease in the proportion of cows calving at BCS less than 3 (from 17\% down to 10\%). Cows with BCS <3 observed as: body outline bony; tail to head slightly recessed; backbones, shoulder, hip bone are visible. Days open and time from cycling to conception were not significantly different each year. As part of the interventions of IVMS, farmers were trained to improve their feeding practices, including: feeding more green feed and giving supplements at late pregnancy and early lactation. Lents et al. (2008) reported that supplementation of cows during early lactation improved milk production and prevented loss of body condition. Similar improvements in the number of Brahman-cross cows in BCS <3 at calving were demonstrated when the same management strategies were promoted to smallholder farmers in Lampung (Tambunan et al. 2013).

The reduced lactation length in 2013 (Table 2) may have assisted cows to return to oestrous quickly. The PPAI can be extended as a result of negative feedback from lactation during suckling, prompting lactational anoestrous. Brahman-cross cows lactating through the dry season in Northern Australia had lower liveweights at the end of the wet season than cows that had been weaned earlier, at the beginning of the dry season (Dollemore et al. 2013). This demonstrates the difficulty for cows to regain liveweight and BCS with extended lactation, and the importance of weaning before nutritional challenge and loss of BCS occurs. The improved management strategies applied in this study, resulted in substantial improvement in the proportion of cows with lactational anoestrous, falling from $50 \%$ in 2011 to $3 \%$ in 2013. There were more cows returning to oestrous while still lactating, resulting in a 2,5-fold improvement in the 100 day in calf rate. Similar improvements in 100 day in calf rate were demonstrated in Brahman-cross cows in Lampung (Tambunan et al. 2013). When a cow becomes pregnant within 100 days of calving, it will lead to producing calf every year and improving farmer income.

Throughout the Project, the majority of cows were mated using AI. The proportion of cows pregnant at first mating increased from 6\% in 2011 to $88 \%$ in 2013. Low reproductive productivity of cattle in Lamongan is therefore likely to be impaired by farmers not detecting signs of oestrous properly. This problem could be caused by many factors, including: silent heat, detecting the wrong sign, and farmers busy with other activities. A long period of PPAI and days open contribute to long of inter-calving interval (Ciccioli et al. 2003).

\section{Calf production}

There was little change in calf production (weight at weaning) during this study (Table 4). The total range of birth weights (2011-2013) did not change during the study, with male calves born at $31-33 \mathrm{~kg}$ and female calves born at $28-31 \mathrm{~kg}$. Average age at weaning decreased by over a month during this study. Average daily gain for calves while suckling was constant throughout this study $(0.7 \mathrm{~kg} / \mathrm{day})$, indicating that cows were directing dietary energy towards maintaining their BCS and reconceiving, rather than increasing milk production for their calves. Calf mortality rate declined during the study. With the support and training provided by the project, farmers have better knowledge of how to manage their new born calves, making sure that calves suckling and getting feed to the cow to produce milk. Improving feeding management needed to increasing milk production so that $\mathrm{ADG}$ calves increased.

\section{CONCLUSION}

The improved management strategies of the IVMS have been shown to increase reproduction rates of Brahman-cross cows in Lamongan district, East Java. Strategies such as maintaining BCS of cows $\geq 3$, appropriate detection of estrous mating management and early weaning at 5-6 months old increased the percentage of cows conceiving within 100 days of calving, and able to produce a calf every year, from $13 \%$ to $33 \%$. The proportion of cows conceiving at first mating increased from $6 \%$ at the start of the study to $88 \%$ at the end. These outcomes are expected to have a significant impact on the economic performance of smallholder cow-calf enterprises.

\section{ACKNOWLEDGEMENTS}

Our gratitude goes to ACIAR for funding this research and all the team of ACIAR project LPS/2008/038, as well as the village farmers, for their cooperation.

\section{REFERENCES}

Affandhy L, Pamungkas D, Ratnawati D. 2009. The effect of weaning age on cow reproductive and calf growth at dryland area. LIPI Widyariset. 12:199-203.

Antari R, Ningrum GP, Mayberry DE, Marsetyo, Pamungkas D, Quigley SP, Poppi DP. 2014a. Rice straw, cassava by-products and tree legumes provide enough energy and nitrogen for liveweight maintenance of Brahman (Bos indicus) cows in Indonesia. Anim Prod Sci. 54:1228-1232.

Antari R, Syahniar TM, Mayberry DE, Marsetyo, Pamungkas D, Anderson ST, Poppi DP. 2014b. Evaluation of village-based diets for increasing the weight and condition of Ongole (Bos indicus) and Bali (Bos 
javanicus) cows in Indonesia. Anim Prod Sci. 54:13681373.

Baruselli PS, Reis EL, Marques MO. 2004. The use of hormonal treatments to improve reproductive performance of anestrous beef cattle in tropical climates. Anim Reprod Sci. 82-83:479-486.

Boland MP, Lanergan P. 2003. Effects of nutrition on fertility in dairy cows advances in dairy technology. Volume 15, page 19. Dublin (Ireland): Faculty of Agriculture, University College Dublin, Belfield.

Budiawan A, Ihsan MN, Wahjuningsih S. 2015. Relationship of body condition score against service per conception and calving interval of PO cows in Babat district of Lamongan. J Livest Trop. 16:34-40.

Burns BM, Fordyce G, Holroyd RG. 2010. A review of factors that impact on the capacity of beef cattle females to conceive, maintain a pregnancy and wean a calfimplications for reproductive efficiency in Northern Australia. Anim Reprod Sci. 122:1-22.

Ciccioli NH, Wettemann RP, Spicer LJ, Lents CA, White FJ, Keishler DH. 2003. Influence of body condition at calving and post partum nutrition on endocrine function and reproductive performance of primiparous beef cows. J Anim Sci. 81:3107-3120.

[DGLAH] Directorate General of Livestock and Animal Health. 2015. Book of livestock statistics. Jakarta (Indones): Directorate General of Livestock and Animal Health, Ministry of Agriculture.

Dollemore W, Quigley S, Poppi D, Mccosker K. 2013. Change in live weight of non-pregnant, mature Bos Indicus cows of different lactational status over the dry season. Northern Beef Research Update Conference. Cairns (Australia): North Australia Beef Research Council: Cairns. p. 163.

Goff JP. 2015. The endocrine system. 13th edition Duke's physiology of domestic animal. Reece WO, editor. Willey Blackwell. p. 617-653.

Lents CA, Heidorn NL, Barb CR, Ford JJ. 2008. Central and peripheral administration of kisspeptin activates gonadotropin but not somatotropin secretion in prepubertal gilts. Reproduction 135: 879-887.

Meikle A, Kulcsar M, Chiliard Y, Febel H, Delavaud C, Cavestany D, Chilibroste P. 2004. Effects of paruty and body condition score at parturition on endocrine and reproductive parameters of the cow. Reproduction. 127:727-737.

Nogueira GP. 2004. Puberty in South American Bos indicus (Zebu) cattle. Anim Reprod Sci. 82-83:361-372.
Poppi DO, Fordyce G, Panjaitan T, Dahlanuddin, Quigley SP. 2011. Developing an integrated production system for Bali cattle in the eastern islands of Indonesia. In: Beef production in crop-livestock systems: Simple approaches for complex problems. ACIAR Monograph No. 145. Winter W, editor. Canberra (Australia): Australian Centre for International Agricultural Research. p. 57-82.

Ratnawati D, Affandhy L, Indrakusuma DA, Mayberry DE, Poppi DP. 2014. Reproductive performance of Brahman cows kept in individual or group pens in East Java, Indonesia. Subandriyo, Kusmartono, Santosa KA, Kurnianto E, Purnomoadi A, Sodiq A, Wiryawan KG, Darodjah S, Inounu I, Darmono, Priyanti A, Wynn P, Han JL, Tay-Hsu J, Idrus Z, editors. Proceedings the 16th AAAP Congress. Yogyakarta (Indones): Gadjah Mada University. p. 1390.

Rusono. 2011. Strategy and policies to accelerate achievement of self-sufficiency of beef cattle 2014 (a concrete study). Directorate of Food and Agriculture. Info Bappenas Studies Vol 8 No 2.

Shelton HM. 2004. Importance of tree resources for dry season feeding and the impact on productivity of livestock farms. Edited by Mannetje, L., L. Ramirez, M. Ibrahim, C. Sandoval, N. Ojeda, J. Ku. Proceedings of the 2nd International Symposium on Silvopastoral Systems: The Importance of Silvopastoral Systems in Rural Livelihoods to Provide Ecosystem Services'. Universidad Autónoma de Yucatán, Merida, Yucatan, Mexico. p. 158-174.

Silvey MW, Haydock KP. 1978. A note of live-weight adjustment for pregnancy in cows. Anim Prod. 27:113116.

Syarifuddin A, Wahdi A. 2008. Reproductive efficiency improvement of Brahman Cross cow through acceleration of estrous postpartum and application of technology Radio Immuno Assay (RIA). Research Grants Character. Faculty of Agriculture Unlam, Banjarbaru.

Tambunan RD, Suminah, Mayberry DE, Fordyce G, Poppi DP. 2013. Reproductive performance of Brahman cows kept by smallholder farmers in Indonesia. Proceedings of the Northern Beef Research Update Conference, Cairns, Australia. p. 184.

Tatman SR, Neuendorrf DA, Wilson TW, Randel RD. 2004. Influence of season of birth on growth and reproductive development of Brahman bulls. Theriogenology. 62:93102.

Walsh SW, Williams EJ, Evans ACO. 2011. A review of the causes of poor fertility in high milk producing dairy cows. Anim Reprod Sci. 123:127-138. 